8. That the division of a stricture by these means will not always ensure a permanent cure if more than the mucous membrane is implicated, unless such parts be divided also.

9. That in cases of intractable stricture, the mucous membrane, the inner layer of involuntary muscle, and the elastic tissue external to it, should be divided, when the operation is done from within, but not the outer layer of muscular fibres, which should remain as a barrier between the stream of urine and the common integuments of the external parts-an accu. racy of division not always to be attained: whence, perhaps, the difficulty of effecting a permanent cure.

10. That when a permanent cure is effected in these cases, the divided elastic wall of the urethra is not re-united by a structure exactly similar to itself, but by common areolar tissue, rendering the part more dilatable under the pressure of the stream of urine; the formation of which dilatation can be aided during the progress of the cure by pressing on the divided part with the point of a solid instrument passed daily for the purpose of preventing, if possible, that contraction which always takes place during the process of cicatrization; a proceeding which cannot be advantageously adopted when the parts are divided through the perinæum, lest it should encourage the formation of a fistulous opening, to which there is always a tendency.

11. That in cases of intractable stricture accompanied by one or more fistulous openings in the perinæum, in young persons, or of middle age, the operation through the external parts, or along the urethra, may be resorted to at the pleasure of the surgeon with an equal chance of success, provided the division of the obstruction or bank preventing the free passage of the urine be effectually divided, the sine quât non of the operation.

12. That the operation within the urethra should always be preferred in elderly persons, particularly if somewhat stout or fat, as less likely to create severe constitutional disturbance, as shown in Case 15; and if this operation should fail from any cause, it by no means interferes with the due performance of the other through the perinæum, which in serious cases then becomes imperative, as the last resource capable of giving relief.

\section{ON A CASE OF PLACENTA PRAEIA.}

\section{By SIDNEY HENSON, L.A.C., \& M.R.C.S. Lond.}

THE following particulars of a case of placenta prævia, with presentation of the hand, in which the hand of the accoucheur was passed through the placenta, and the child turned, the mother recovering, may be considered worthy of insertion in The LanCET.

The patient, who is about five-and-thirty years of age, and a strong, healthy woman, was seized with labour on Saturday the $12 \mathrm{th}$ ult. It was her 10 th pregnancy. On my arrival, I immediately made a vaginal examination, and found the membranes protruding, and the os uteri very dilatable. Not being able to satisfy myself as to the presentation, I was going to make a second examination a few minutes afterwards, when the membranes ruptured, an unusnally large quantity of liquor amnii escaping. On making my second examination, I found that the placenta was situated almost immediately over the os uteri. I then inquired if there had been any hæmorrhage previously during her pregnancy, but she distinctly assured me there had not been, which rather puzzled me, though I was quite certain that it was the placental mass which I felt presenting.

For a short time there was a good deal of hæmorrhage during the intervals between the pains, and I was about proceeding either to detach the placenta, or pass my hand through it, and endeavour to turn the child (an operation which I have never yet performed), when the pains receded, the hæemorrhage almost ceasing; there being so little that 1 did not think that there was occasion for inmmediate interference, particularly as the woman felt perfectly sure that the child was dead, not having felt it move for three or four days.

Here I would state that the case was not one of my own; but one which $I$ was called to attend during the absence of the gentleman who was to have attended, Mr. Pettinger, of Sutton-on-Trent, a gentleman who has been in practice nearly thirty years. Feeling, however, that $I$ should like to have some other opinion, I sent to ask Mr. Gilby, of sutton, whom I had met at an operation a short time before, to have the goodness to ride over and see the case, which he very
On examination, Mr. Gilby found the placenta presenting, the hæmorrhage being very slight and no pains; he agreed with me that although interference would be requisite, yet there was no immediate occasion for it.

Under these circumstances, I preferred waiting for $\mathbf{M r}$. Pettinger's return, and I afterwards congratulated myself that I did so. I thought that I conld feel the hand presenting beyond the placenta, but I could not be sure.

On Mr. Pettinger's arrival, he found the patient without any uterine contractions whatever, there being very little hæmor rhage, and her pulse good. He immediately passed his hand through the placenta, when he found the hand of the foetus presenting. He then endeavoured to turn the child, which, after great exertion, he failed to do, and was compelled to allow the uterus to expel his hand. The pains came on again almost immediately after Mr. Pettinger had passed his hand through the placenta, being very powerful ones indeed. I then attempted to turn, but after some time was compelled to allow my hand to be expelled also. I succeeded, however in getting the hand of the child up into the uterus, but it came down again.

However, after the administration of one drachm of tinc ture of opium, Mr. Pettinger succeeded in getting one foot down, to which I tied a piece of tape, which I held securely. At this time, both a hand and a foot protruded. The former was shortly however returned, and the other foot brought down; soon after which, the child was expelled, to the great delight of not only the mother, but my friend Mr. Pettinger and myself, as he said he had never met with such a case before. To conclude, the patient convalesced very nicely. The following day there was a little tenderness over the region of the left ovary, which, however, was relieved by a few leeches. She is now at work peeling rods, a common occupation here at this time of the year for women of the lower class. The child, I need hardly say, was dead, as it had evidently been for two or three days, but was a fine, full-grown male.

Tuxford, Notts, May, 1851.

\section{INTRA-UTERINE POLYPUS SPONTANEOUSLY CAST OFF.}

BY WALTER CHAPMAN, Esq., M.R.C.S., Surrey.

M- G-, aged thirty-five, a highly respectable unmarried woman, of very delicate aspect, enjoyed good health until May, 1844. The catamenia appeared when she was between fourteen and fifteen years of age, and continued regular. At the time stated, her illness commenced with more or less of leucorrhoea, loss of appetite, emaciation, and debility, the catameniæ recurring properly. Thus she continued for three years, during which she was under the care of an experienced and intelligent practitioner, without deriving any decided benefit. In 1847, she submitted to an internal examination, but nothing abnormal was detected. In the following year she began to perceive an augmentation of size in the hypogastric region, and to suffer severe pains, having the character of those of labour, and more particularly at the menstrual periods. In March, 1849, she consulted Dr. Lever, who made a vaginal examination, and pronounced her to have "a polypus in the womb." I first saw her in April of the same year, and found her suffering greatly, from inability to void her urine, (rendering it necessary to pass the catheter,) and from an almost constant uterine bæmorrhage, the blood sometimes gushing away, at others slowly draining; she was very much anæmiated and emaciated; there was frequent vomiting: and almost constantly great pain in the back, loins, and uterine region, these pains frequently becoming exceedingly severe, resembling those of parturition, and preventing her from obtaining either rest or sleep, except for very short periods.

On making an external abdominal examination, a large globular moveable tumour could be very distinctly felt in the hypogastrium: its size was about equal to that of the uterus directly after the completion of labour at the full period, and could quite as readily be felt; it was not very painful or tender to the touch. An internal examination discovered the vagina to be very small, and narrowed superiorly, the os uteri to be so closed as not to admit the tip of the finger, and the uterus itself moveable and large, as if from something in its cavity.

In this sad state she continued till April, 1850, with an aggravation of all her symptoms; and her death seemed quite inevitable, from their combined effects. There was no altera. tion in the state of the os uteri.

Dr. Lever saw her with me again about this time, and 
thought her only chance of safety depended upon the uterus being able to expel its contents into the vagina, so as to allow of their being removed from thence by ligature.

One morning in April, 1850, her mother (who is a very sensible woman) showed me a whitish substance, like a shred of fibrine, which had passed per vaginam; it was very tenacious, and not offensive. From this time, many of these shreds or masses continued to be expelled, some requiring to be extracted from the vagina, till a quantity escaped more than sufficient to fill a pint basin. Three months elapsed before the whole of this mass was voided; two or three days sometimes passed without any more escaping. As it came away, the tumour proportionately diminished in size, the hamorrhage ceased, the pains gradually disappeared, and she began to obtain rest, and to recover her appetite and strength: at the end of June, 1850 , she was able to walk out of doors. In about three weeks more, the catamenia again appeared naturally, and have since continued to do so, without any discharge in the intervals; and at the present time, and for so many months past, she pronounces herself to be quite well, and has the appearance of being in perfect health.

I should mention, that during the last twelve months of her sufferings, in opposition to the earnest entreaties of Dr. Lever and myself, she (thinking her recovery impossible) would not permit any vaginal plug to be used, and refused, almost entirely, to tale any kind of remedy, even morphia or opium.

Dr. Lever informed me that he considered this a very rare case, there being only three or four upon record of a similar kind.

Lower Tooting, Surrey, May 13, 1851

\section{ON SULPHURIC ACID.}

BY DR. SHERIDAN MUSPRATT, F.R.S.E., PROFESSOR OF THE LIVERTOOL COLEEGE OF CHEMISTRY.

IT is mentioned in several of the leading works upon chemistry, that sulphuric acid, with a specific gravity of $1 \cdot 78$, contains 68 per cent. of anhydrous acid. I infer, from some recent experiments, that commercial, and not the pure acid is meant. Liverpool "oil of vitriol," having a specific gravity of 1.784 , yields me 68.47 of dry acid; but it contains the following impurities: hydrochloric, nitrous, nitric acids, potassa, lead, selenium, titanium, lime, magnesia, arsenic, tin, iron, copper, organic matter, dic. No recent experiments have been made upon this subject, so that many persons have only the data of Dalton, Vauquelin, and Berthollet, to go by, arrived at many years ago.

Having been lately consulted by a manufacturer, with respect to oil of vitriol of a certain density, $I$ investigated the subject, and found that pure sulphuric acid, at $32^{\circ}$, specific gravity $1 \cdot 767$, gave the annexed:-

$$
\begin{array}{lllllll}
\text { Dry acid } & \ldots & \ldots & \ldots & \ldots & \ldots & 72.97-73.01 \\
\text { Water } & \ldots & \ldots & \ldots & \ldots & \ldots & 27.03-26.99 \\
\hline
\end{array}
$$

\section{Corresponding to the formula}

$$
2\left(\mathrm{HO} \mathrm{SO}_{3}\right)+a q .
$$

Its boiling point was $251.5^{\circ}$.

When dilnte sulphuric acid is boiled, only water is evolved at first, no fumes mixing with the aqneous vapour until the residue becomes $2 \mathrm{H} \mathrm{O}, \mathrm{S} \mathrm{O}_{3}$. This, $\mathrm{I}$ believe, has also been noticed by Graham.

Pure oil of vitriol, specific gravity $1 \cdot 84$, contains, theoretically, 81.63 per cent. of anhydrons acid. Dalton only gives 81.00 . I have obtained, by experiment, 81.68 per cent.

The preceding results will, $I$ think, prove interesting to many of the readers of this valuable journal.

College of Chemistry, Liverpool, May 27, 1851 .

Foundling Hospital.-About ninety of the governors and friends of this charity entertained his Royal Highness the Duke of Cambridge at dinner on Friday last, within the walls, on the appointment of his Royal Highness to the office of President of the Corporation. The Lord Chief Baron Pollock took the chair. The objects and purposes of the charity were feel. ingly and appropriately stated by his Royal Highness and the Lord Chief Baron; previous to which about 400 of the poor children paraded the dining-hall.

\author{
A fmirror \\ OF THE PRACTICE OF
}

MEDICINE $\underset{\text { IN THE }}{\text { AND SURGERY }}$
HOSPITALS OF LONDON.

Nulla est alia pro certo noscendi via, nisi quam plurimas et morborum, ot dissectionum historias, tum aliorum proprias, collectas habere et inter se comparare,-Morgagni. De Sed. et Caus. Morb., lib. 14. Proomium.

\section{ST. BARTHOLOMEW'S HOSPITAL. Cancrum Oris; Recovery.}

(Under the care of Dr. Burrows.)

Pathologists have not as yet determined how it comes to pass that mercury has a direct action on the salivary glands, and produces more or less severe stomatitis; nor is it much clearer why, under certain circumstances, the mouth of young subjects is attacked with a gangrenous inflammation which often destroys the patient. Whatever may be the final cause of the latter phenomenon, it is of a very important nature, both to the physician and the surgeon; for in this affection, as well as in a few others, medicine and surgery are closely blended.

We are accustomed to look for cancrum oris in children aged from five to ten years, or from two to eight years, but it would appear from the age of the patient (thirteen years) lately under the care of Dr. Burrows, that a very early age is not an invariable circumstance. Adults, however, seem quite free from this peculiar affection, for it is stated by Taupin, that in a total number of 1900 cases attended by him at the Hôtel Dieu at Paris, in 1837, only one adult suffered with cancrum oris. The latter manifestation is generally said to attack children exposed for some length of time to debilitating causes; and what Richter calls the metastatic species supervenes on acute exanthematous diseases; it is likewise maintained that measles take the lead as a predisposing cause. To these opinions should be added, as will become apparent by the subjoined case, that common continued fever may be accompanied by gangrene of the mouth, thongh it would seem that in such cases the ulcerative process does not go so far as to cause the perforation of the cheek.

That the disease is very dangerous and frequently proves fatal, has been acknowledged by all observers, the proportion of deaths depending very probably on the variety of the affection, namely, whether it be:-1st, peculiar to infants at the breast; 2 nd, attacking children enfeebled by some previous disease; or, 3rd, confined to the cheeks and lips (Cumin.) We now beg a few moments' attention to the following case. Einma $\mathrm{H}-$ - thirteen years of age, was admitted into Faith ward, under the care of Dr. Burrows, Dec. 18, 1850 Her countenance is pale, languid, and heavy, the pupils dilated, the conjunctivæ suffused; the skin is warm and rather moist, but no rash or sudamina can be observed upon it. The tongue presents a dry and brown fur in its centre, the abdomen is soft, moderately painful on pressure in the lower portion, and especially round the umbilicus.

Alvine evacuations have been liquid, dark, and bilious, there has been some vomiting, and the patient states that she has been ill three weeks, the complaint having begun with pain in the limbs and back; delirium had set in two days before admission, and purging and romiting had continued for the same period.

Dr. Burrows ordered wine and beef-tea; the hair to be shaved, and cold lotion applied to it, if necessary; four leeches to the abdomen, and a mercurial purgative. From this period to the twelfth day after admission, the patient went through the different phases of mild typhoid fever withont maculæ, when she appeared much improved; but the right cheek was now noticed to be swollen, the patient having the night previously been rather restless. The patient complained, however, of no pain, though the face continued to swell, and was becoming red. She was ordered to take chlorate of potash with bark, and to use a gargle of chloride of soda. Mr. Stanley being consulted, advised the application of nitric acid, if the cheek did not improve.

There was now noticed, on the internal aspect of the cheek, 